\title{
Water-uptake properties of a fish protein-based superabsorbent hydrogel chemically modified with ethanol
}

\author{
Vilásia Guimarães Martins ${ }^{1}$, Jorge Alberto Vieira Costa $^{2}$ and Carlos Prentice ${ }^{1 *}$ \\ 'Laboratório de Tecnologia de Alimentos, Escola de Química e Alimentos - EQA, \\ Universidade Federal do Rio Grande - FURG, Rio Grande, RS, Brasil \\ ${ }^{2}$ Laboratório de Engenharia Bioquímica, Escola de Química e Alimentos - EQA, \\ Universidade Federal do Rio Grande - FURG, Rio Grande, RS, Brasil \\ *dqmprent@furg.br
}

\begin{abstract}
Hydrophilic polymers can form hydrogels, which are able to absorb and retain as much water as one hundred times their weight. Polymers based on natural products have been drawing attention since they are biocompatible, biodegradable and nontoxic. The aims of this study were to produce and to characterize a biopolymer with superabsorbent properties from fish protein isolates. Hydrogels were produced from protein isolates from Whitemouth croaker processing wastes chemically modified. The extension of change in lysine residues, kinetics in water-uptake capacity, $\mathrm{pH}$ effect, ionic strength over the absorption of water by hydrogels and the behavior of the biopolymer when subject to successive hydration and dehydrations were investigated. Results showed that acid modified protein without ethanol treatment reached a maximum absorption of $103.25 \mathrm{~g}_{\text {water }} / \mathrm{g}_{\text {dry gel }}$, while the same sample modified with ethanol reached $216.05 \mathrm{~g}_{\text {water }} / \mathrm{g}_{\text {dry gel }}$
\end{abstract}

Keywords: biopolymer, ethanol, fish wastes, protein isolates, superabsorbent.

\section{Introduction}

Protein-based materials have the potential to solve a vast array of technical challenges ${ }^{[1]}$. The recovery and modification of fish proteins present in by-products and their application, such as, in industrial products is a promising and exciting alternative ${ }^{[2]}$. For industry, developing processes to recover and to use the wastes from fish processing becomes economically feasible instead of discarding them ${ }^{[3,4]}$.

Approximately $50 \%$ of the whole fish is considered waste after processing and it is not applied as food ${ }^{[5,6]}$. The world population has grown and the fish quantity caught nowadays values of approximately 100 million tons/year suggest that the estimate of sustainability is exceeded and obviously this increase leads to the necessity of more intelligent and cautious use of water resources ${ }^{[5]}$.

Alternatively, chemical hydrolysis focuses on biomass recovery from fish results in a soluble product, known as fish protein isolate ${ }^{[7]}$. The soluble isolate is submitted to dehydration, which increases the stability and protein content ${ }^{[8]}$.

Fish protein tends to have higher application, with inherent capacity of water uptake since the fish proteins are richer in lysine than vegetables ${ }^{[9]}$. Some of lysine residues $\left(-\mathrm{NH}_{2}\right)$ of proteins could be replaced by carboxylic group using a reaction with ethylenediamine tetraacetic dianhydride and such modification in the protein may lead to a hydrogel with higher water retention capacity and transparency ${ }^{[5]}$.

Chemical changes in protein became common in the 1950 s, when the techniques were originally developed to help the structural analysis of protein molecules. The purpose of such changes was to find out the number of residual amino acids in a protein molecule in the physical-chemical state, as well as, to identify amino acid residues that have a particular role in the protein ${ }^{[10]}$.

Protein chemical changes allow the introduction and exposure of functional groups, which are unattainable through conventional techniques of mutagenicity ${ }^{[11]}$. This technique is also applied to change the specificity of enzymes and in the pharmaceutical industry it helps to understand how drugs works ${ }^{[12,13]}$.

Such modifications do not change the characteristics of protein biodegradability and biocompatibility. However, suitable properties may be enhanced and then, some highly toxic synthetic polymers, unwanted in many applications, can be replaced by these natural polymers. In the last years, there has been an increasing interest in biodegradable polymers from renewable sources. Hydrophilicity and water absorption are the most required characteristics when absorbent materials are developed. Polymers designed from natural products, such as, polysaccharides and proteins, consist in materials of interest and are available at low $\operatorname{cost}^{[14]}$.

Hydrogels are solid polymer structures, which contain a significant fraction of water, regularly above $90 \%$. The tridimensional polymeric structure of hydrogel is usually made by cross-link, not only by physical interactions, such as, Van der Waals or hydrogen links, but by covalent links created by crosslinking agents or gamma-irradiation ${ }^{[5,15]}$. Due to their high water content, tissue-mimic physical and mechanical properties and biocompatibility, hydrogels have potential to be used in numerous biomedical applications 
such as tissue repair, reconstructive surgery, drug delivery and cell encapsulation ${ }^{[16,17]}$.

The development of new hydrogels with high capacity of absorption from natural polymers has been of invaluable importance due to a great potential of its application as material to immobilize enzymes and the large capacity of water retention ${ }^{[18]}$. Hydrogels are highly biocompatible because they have a close structural resemblance to the natural extracellular matrix $(\mathrm{ECM})^{[17,19]}$. Biodegradable polymers may be consumed by microorganisms and are reduced to simple compounds, such as, carbon dioxide, water and ammonia ${ }^{[20,21]}$.

Hydrogels based on proteins are able to absorb between 80 and $300 \mathrm{~g}$ of water per gram of dry gel, depending on the extension of modification, crosslinking density and protein concentration used during the process ${ }^{[2]}$. It has been reported that after adding the crosslinking agent, a significant amount of folded structures remain, such as, $\alpha$-helix, and $\beta$-sheet, in protein polymers, and these structures enable the hydrogel to absorb a smaller amount of liquid, as these structures may oppose to relaxing the protein chain, affecting water diffusion inside the tridimensional chain ${ }^{[17,22]}$. By converting these twisted protein structures in a more linear chain, it is possible to increase the capacity of water uptake, in order to proceed with the denaturation of $\beta$-sheet structure and this is accomplished by adding organic solvents ${ }^{[5]}$.

This study aimed to produce and characterize a superabsorbent protein hydrogel, through the treatment of fish protein isolates, obtained from Whitemouth croaker, modified chemically with ethanol, an organic solvent.

\section{Materials and Methods}

\subsection{Material}

Whitemouth croaker (Micropogonias furnieri) were obtained from fish processing industries of Rio Grande, Southern Brazil. The fishes were transported in ice-filled containers to the Laboratory of Food Technology, where fish protein isolation was carried out. Firstly, the fish was filleted, after having separated the residue, it was washed up with chlorine water and grounded in equipment with an endless screw, and it was afterwards frozen at $-18{ }^{\circ} \mathrm{C}$ until its use.

Ethylenediamine tetraacetic dianhydride (EDTAD) and glutaraldehyde were purchased from Sigma-Aldrich, United States. All the other reagents used were analytical grade.

\subsection{Isolation of Whitemouth croaker protein}

Two types of chemical extraction processes to isolate protein were performed, alkaline and acid solubilization, applying the $\mathrm{pH}$ shifting process according to Martins et al. ${ }^{[5]}$ and Martins et al. ${ }^{[23]}$. The samples were homogenized with distillated water at a ratio of 1:5. The chemical processes were carried out in a jacketed reactor associated with a thermostatic bath and coupled to an agitator. $1 \mathrm{M} \mathrm{NaOH}$ was applied as the alkaline agent and $1 \mathrm{~N} \mathrm{HCl}$ as the acidifying acid, the alkaline solubilization was done during $20 \mathrm{~min}$ at $20^{\circ} \mathrm{C}$ at $\mathrm{pH} 11$ and the acid solubilization during $20 \mathrm{~min}$ at $30^{\circ} \mathrm{C}$ at $\mathrm{pH}$ 2.5. After solubilization, the hydrolysate was centrifuged at $7500 \mathrm{x} g$ for $15 \mathrm{~min}$. In this centrifugation, the sample was separated in three phases, the superior phase (lipids) and the lower phase (insoluble proteins) were discarded, and the intermediate phase (soluble proteins) was submitted to acid and alkaline precipitation until it reached proteins isoelectric point $(\mathrm{pH}=5)$, where $1 \mathrm{~N} \mathrm{HCl}$ was applied as acidifying and $1 \mathrm{M} \mathrm{NaOH}$ as the alkalizing one, with exposure time of $20 \mathrm{~min}$ at $30^{\circ} \mathrm{C}$ under agitation. Afterwards, a new centrifugation was done at $7500 \times \mathrm{g}$ for $15 \mathrm{~min}$, where the supernatant was discarded and the precipitate, which is the protein isolate, was stored at $-18^{\circ} \mathrm{C}$ until it was lyophilized.

\subsection{Modification of Whitemouth croaker protein isolates}

The fish protein isolates were modified with ethylenediamine tetraacetic dianhydride (EDTAD) according to the method described by Hwang and Damodaran ${ }^{[24]}$. A protein solution of $1 \%$ was adjusted to $\mathrm{pH} 12$ with a solution of $1 \mathrm{~N} \mathrm{NaOH}$ and then heated at $65{ }^{\circ} \mathrm{C}$ for $30 \mathrm{~min}$ and cooled in an ice bath in order to return to room temperature. The pre-treated protein was reacted with solid EDTAD. During the period of reaction of 2-3 h, the protein solution was mixed constantly; incremented amounts of dianhydride were added during the first 30-90 $\mathrm{min}$, the reaction occurred at room temperature, and the $\mathrm{pH}$ of the protein solution, throughout the reaction, was kept constant by adding $1 \mathrm{~N} \mathrm{NaOH}$. The reaction ended when $\mathrm{pH}$ remained constant for $30 \mathrm{~min}$. Then, the $\mathrm{pH}$ of protein solution was adjusted to 7 and dialyzed exhaustively with deionized water for $24 \mathrm{~h}$ at $4{ }^{\circ} \mathrm{C}$ in membranes of molecular weight $6000-8000 \mathrm{kDa}$. The modified protein was then lyophilized at a pressure of $121 \times 10^{-3} \mathrm{Mbar}$ and collector at $-48{ }^{\circ} \mathrm{C}$ was applied in a Liotop model L108

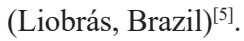

\subsection{Determination of protein content}

Determination of protein content from the modified isolate was carried out with the method described by Scopes ${ }^{[25]}$, which applies ultraviolet absorption at two wave lengths (205 and $280 \mathrm{~nm}$ ) and two protein concentrations, 5-25 $\mu \mathrm{g}$ $\mathrm{mL}^{-1}$ at $205 \mathrm{~nm}$ and $50-1000 \mu \mathrm{g} \mathrm{mL}^{-1}$ at $280 \mathrm{~nm}$, for such analysis the samples must be purified, generally dialyzed and lyophilized. The error in this method is estimated at less than $2 \%$. The protein content was determined according to Equation 1.

$$
P(m g / m L)=\frac{A_{250}}{27+120\left(A_{280} / A_{205}\right)}
$$

\subsection{Extension of modification}

The extension of acetylation was expressed as a percentage of the total modified residual lysine. The unmodified lysine content and acetylated proteins were determined by the acid method 2,4,6-trinitrobenzenosulfonic (TNBS) as described by Hall et al. ${ }^{[26]}$. For $1 \mathrm{~mL}$ of $4 \%$ of $\mathrm{NaHCO}_{3}, 0.8 \mathrm{~mL}$ of a solution containing less than $5 \mathrm{mg}$ of protein was added, followed by the addition of $0.2 \mathrm{~mL}$ solution of TNBS (12.5 $\mathrm{mg} \mathrm{mL}^{-1}$ ). The mixture was incubated at $40{ }^{\circ} \mathrm{C}$ for $2 \mathrm{~h}$, and $3.5 \mathrm{~mL}$ of $\mathrm{HCl}$ concentrate was added. The tube was covered and kept at $110{ }^{\circ} \mathrm{C}$ for $3 \mathrm{~h}$ and then, after cooling, the volume was filled up to $10 \mathrm{~mL}$ with deionized water. The solution was extracted twice with ethylic ether. The tube was uncovered and kept at $40^{\circ} \mathrm{C}$ to allow the residue of ether 
to evaporate. Absorbance of yellow solution ( $\varepsilon$-TNP lysine) was measured at $415 \mathrm{~nm}$. The amount of residue reactive to the lysine from acetylated and non-acetylated proteins was determined from standard curve using lysine.

\subsection{Crosslinking by glutaraldehyde}

A solution of $10 \%$ of fish modified isolates with EDTAD was adjusted to $\mathrm{pH} 9$ by adding a solution of $1 \mathrm{~N} \mathrm{NaOH}$ and homogenized, its volume was $10 \mathrm{~mL}$. A solution of glutaraldehyde $25 \%$ at a ratio of $0.02: 1$ (glutaraldehyde/protein, $\mathrm{p} / \mathrm{p}$ ) was then added to it. After adding the crosslinking agent, the solution was homogenized, and left overnight at room temperature ${ }^{[5]}$.

\subsection{Treatment with ethanol}

After crosslinking, the sample was divided into two parts, one of them placed in an oven at $40{ }^{\circ} \mathrm{C}$ for $48 \mathrm{~h}$, in order to be dried and grounded, and the other part was suspended in ethanol for $3 \mathrm{~h}$, during this period ethanol was changed at least twice. The treatment with ethanol causes denaturation of protein and dehydration of gel. At the end of the treatment with ethanol, the gel was in the shape of dry particles, although the gel was put in an oven at $40{ }^{\circ} \mathrm{C}$ for $2 \mathrm{~h}$ to remove the ethanol residue and moisture ${ }^{[27]}$.

\subsection{Kinetics of gel water-uptake}

A sample of gel of 20-30 mg was placed in an envelope $(4 \times 6 \mathrm{~cm})$ from nylon and a paper complex (Bolmet Inc.), which was later hot sealed. This envelope was submerged in Milli-Q water for 2, 4, 6, 8, 10 and $24 \mathrm{~h}$, then it was centrifuged at $214 \mathrm{x} g$ for $5 \mathrm{~min}$, and weighted immediately. All the studies of water absorption were carried out at room temperature $\left(25 \pm 2{ }^{\circ} \mathrm{C}\right)$. The amount of water absorbed by gel was determined by the weight of water absorbed divided by the weight of dry gel. Drying of gel took place in an oven at $105{ }^{\circ} \mathrm{C}$ until constant weight ${ }^{[5]}$. All the swelling experiments were performed in triplicate.

\subsection{Effect of ionic strength over water uptake capacity of gel}

The influence of ionic strength over swelling property of gels was tested by immersion of the samples in solutions with different concentrations of $\mathrm{NaCl}$, from 0.01 to $0.15 \mathrm{M}$ for a period of $24 \mathrm{~h}$ at room temperature $\left(25 \pm 2{ }^{\circ} \mathrm{C}\right)$. Later, the samples were centrifuged at $214 \times \mathrm{g}$ for $5 \mathrm{~min}$ and weighted immediately. The amount of water absorbed was calculated by the weight of water obtained divided by the weight of dried gel. The gel was dried in an oven at $105^{\circ} \mathrm{C}$ until constant weight. A control sample was also made, without adding salt.

\subsection{Effect of $\mathrm{pH}$ on the water-uptake capacity}

The influence of $\mathrm{pH}$ over the behavior of water absorption of hydrogel was determined by placing dried gel samples in buffers of different $\mathrm{pH}$, ranging from 3 to 10 at room temperature for a period of $24 \mathrm{~h}$. The buffer applied in this study were $\mathrm{pH} 3$ (formic acid); $\mathrm{pH} 4$ (benzoic acid); pH 5 (acetic acid); pH 6 (MES); pH 7 (phosphate buffer);
pH 8 (tris base); $\mathrm{pH} 9$ (tris base) and $\mathrm{pH} 10$ (CAPS). All the buffers were prepared with the same ionic strength of $0.01^{[5]}$.

\section{$2.11 \mathrm{Gel}$ absorption and reversibility}

For the study of swelling kinetics, the samples were immersed in deionized water. At regular intervals of time, the samples were removed, centrifuged at $214 \mathrm{x} g$ for $5 \mathrm{~min}$ and weighted. Reversibility of absorption and dissolution of the gel was determined by the use of the same samples for sequential absorption in deionized water and dissolution in solution of $0.15 \mathrm{M} \mathrm{NaCl}$.

\section{Results and Discussion}

The lyophilized fish waste presented $64.3 \%$ of protein content. The acid and alkaline isolate reached 86.9 and $72.3 \%$ of protein, respectively. The yield of each isolate was $55.87 \%$ (acid isolate) and $46.48 \%$ (alkaline isolate).

\subsection{Extent of chemical modification}

Chemical modification of protein isolates was carried out using ethylenediamine tetraacetic dianhydride (EDTAD) in proportions which range from 0.05:1 to 0.5:1 (EDTAD:protein, $\mathrm{w} / \mathrm{w})^{[5]}$, the best results were achieved in the isolates modified with 0.2:1 and 0.5:1 (EDTAD:protein, w/w). Therefore, only these ones were tested in the remaining part of the study. Table 1 shows the results obtained for each isolate.

The extent of modification is related to the amount of residue of lysine present in the isolates, as well as, the amount of chemical agent added during the process of hydrogel production. In the alkaline isolate, the initial amount of lysine found was $11.73 \%$ and in the acid isolate it was $11.86 \%$, which is in agreement with the literature, as fish protein presents between 10 and $12 \%$ of lysine ${ }^{[28]}$.

The chemical modification of lysyl residues with a tetracarboxylic dianhydride introduces a large number of carboxyl groups into a protein molecule. These added carboxyl groups, in addition to causing extensive unfolding of the protein molecule via intramolecular electrostatic repulsion, would impart a polyanionic character to the protein with numerous sites for water binding ${ }^{[5]}$. It is possible to verify the modification of the isolate through the increase in the number of lysine modified residues with the increase of EDTAD (Table 1).

During the chemical modification of proteins, it is ideal to stop the process when it reaches lysine modification residues between 50 and $80 \%$, since an extension in the process would lead to the production of a hydrogel with reduced water-uptake capacity. An extensively modified protein would have many linking sites for water, although it would have less space for its absorption, the opposite would be also undesirable, since a slightly modified protein would,

Table 1. Extent of modification of Whitemouth croaker protein isolates in different proportion of EDTAD:protein $(\mathrm{w} / \mathrm{w})$.

\begin{tabular}{ccclcc}
\hline & $\mathbf{0 . 0 5 : 1}$ & $\mathbf{0 . 0 8 : 1}$ & $\mathbf{0 . 1 : 1}$ & $\mathbf{0 . 2 : 1}$ & $\mathbf{0 . 5 : 1}$ \\
\hline Acid (\%) & 16.63 & 24.61 & 46.2 & 61.35 & 72.41 \\
Alkaline (\%) & 13.42 & 15.86 & 33.69 & 45.76 & 63.5 \\
\hline
\end{tabular}


probably, has fewer water binding sites, and consequently a hydrogel with low capacity of water uptake.

Rathna et al. ${ }^{[22]}$ applied modified albumin with EDTAD to produce hydrogel, however, heating was applied to form the gels. The researchers observed that the larger extension of modification resulted in higher water-uptake capacity, although proteins with high degree of modification had less density of crosslinking and they eventually disintegrated, for instance, modified hydrogel $100 \%$ disintegrated after $3 \mathrm{~h}$, while hydrogel prepared with $83 \%$ took $5 \mathrm{~h}$ to disintegrate.

According to Hwang and Damodaran ${ }^{[27]}$, through chemical modification of lysine residues with an ethylenediamine tetracarboxylic it is possible to introduce a large amount of carboxylic groups inside the protein molecule. For each lysine residue modified, up to three carboxylic groups can be introduced in the protein.

The modified protein with EDTAD is nontoxic; there are no reactive groups, besides the carboxylic groups which are introduced in the molecule of the protein. During the reaction, EDTAD reacts with water and it is converted in sodium salt EDTA, the Na EDTA is considered a safe food additive, thus, it does not pose risks to human health ${ }^{[29]}$.

\subsection{Kinetics of water-uptake}

For practical applications, as diapers, plants water supply and any other product that need absorb water or keep water to release, both high capacity of water-uptake and high rate of retention are required. Buchholz ${ }^{[30]}$ suggests that the kinetics of water-uptake of superabsorbent materials is influenced by many factors, such as, capacity of water retention, size of particles and polymer composition.

During the hydrogel production, glutaraldehyde was added at proportion of 0.02:1 (glutaraldehyde:protein, $\mathrm{p} / \mathrm{p}$ ). It has been proved by several authors that an increase in the amount of glutaraldehyde interferes in water uptake. Some studies show that the higher amount of crosslinking agent during hydrogel production leads to a drop in the amount of water absorbed by the gel ${ }^{[31,32]}$. According to Hwang and
Damodaran $^{[27]}$, this is due to the capacity of water-uptake, since by raising the crosslinking density between the protein molecules, reduces the space for water absorption inside the tridimensional network.

It is reported that after the stage of adding the cross linking agent during the process of hydrogel production, a significant amount of folded structures remain, such as, $\alpha$-helix and $\beta$-sheet, these structures may lead the hydrogel to absorb less amounts of liquid, these structures may oppose the protein chain relaxation, affecting water diffusion inside the tridimensional network ${ }^{[27]}$.

One way to increase water absorption is to turn these twisted structures into more linear ones, using organic solvents. This way it is possible to denature such structures and make them more linear, thus more sites are exposed for water binding and there are more spaces for swelling inside the protein molecule.

By denaturing the polypeptide chains in situ in the protein matrix, it is apparently possible to avoid refolding these structures, even after removing the reagent that provides denaturation. This procedure increases the flexibility of protein chains and relaxes the tridimensional gel network, such as, water diffusion inside the polymeric chain ${ }^{[9]}$.

Figure 1 presents the kinetics of water-uptake of protein modified isolates during a period of $24 \mathrm{~h}$. It is possible to verify that the samples treated with ethanol had higher water absorption than the samples treated only with glutaraldehyde. In $24 \mathrm{~h}$, the control samples obtained maximum water uptake of $7.03 \mathrm{~g}_{\text {water }} / \mathrm{g}_{\text {drygel }}$ and $9.22 \mathrm{~g}_{\text {water }} / \mathrm{g}_{\text {drygel }}$, for hydrolyzed, alkaline and acid, respectively. Samples modified chemically reached much higher values.

The highest rate of water absorption occurred within the first hours of immersion, in the alkaline modified isolates it is observed until $2 \mathrm{~h}$ of immersion that the water absorption became virtually constant until the last period of $24 \mathrm{~h}$, after that only a slight increase in water retention is noticed. In the acid modified isolates the same trend was observed, although both modified isolates treated with ethanol had (a)

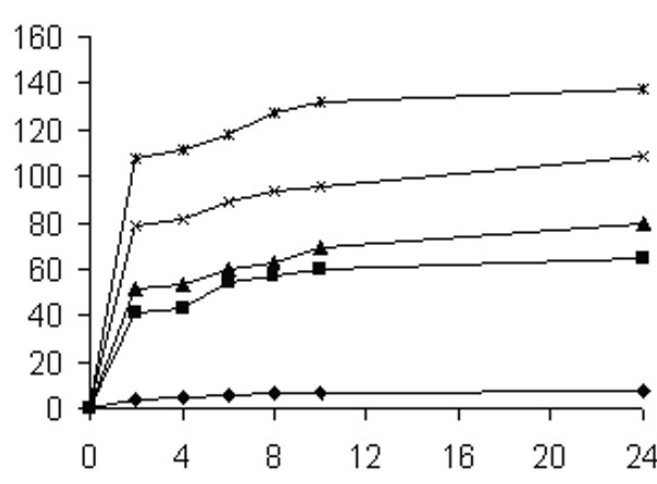

Time (h) (b)

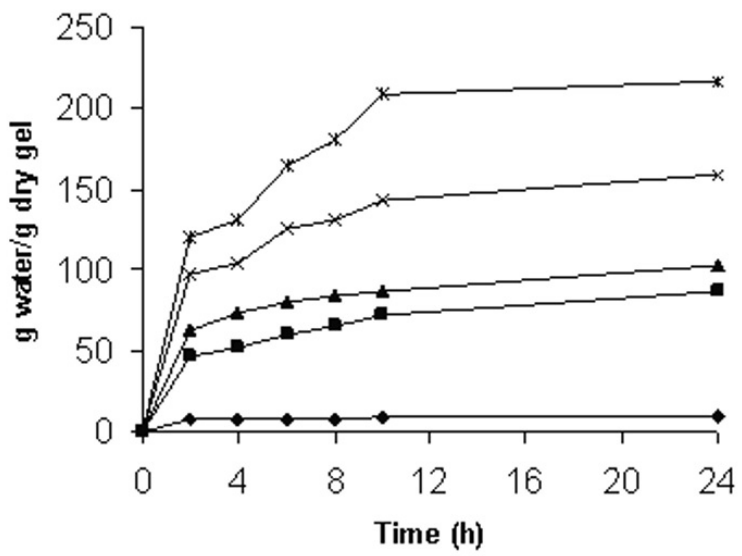

Figure 1. Kinetics of water absorption of hydrogels. (a) Alkaline modified isolates (b) acid modified isolates. alkaline and acid isolates without chemical modification; modified 0.2:1 (EDTAD:protein, p/p); $\boldsymbol{\Delta}$ modified 0.5:1 (EDTAD:protein, p/p); $\times$ modified 0.2:1 treated com ethanol; * modified $0.5: 1$ treated com ethanol. 
sharper increase between 2 and $10 \mathrm{~h}$, when compared with other samples, after this period, they reached stability until the period of $24 \mathrm{~h}$.

The alkaline modified isolates showed lower water retention capacity than the acid modified isolates, as expected, the extent of modification was larger in acid modified isolates. A higher water uptake is reached when it has more carboxylic groups inside of the protein molecule and it is possible because of the chemical modification of the lysine residues, the chemical reaction with the EDTAD make the substitution of $\mathrm{NH}_{2}$ for carboxyl groups. The alkaline and acid modified isolates $0.5: 1$ exhibited water retention capacity 11 times higher than the non-modified hydrolysates and the modified 0.5:1 treated with ethanol showed water retention capacity 19 times higher for alkaline and 23 times higher for acid.

In a similar study carried out by Rathna and Damodaran ${ }^{[9]}$ with fish modified hydrolysates, it was shown that the modified isolates treated with ethanol had increased capacity of water-uptake of approximately $50 \%$ when compared with those without treatment with ethanol. According to García Sánchez and Cortés Ortega ${ }^{[16]}$, the aqueous solution with ethanol stabilizes growing particles, running as the continuous phase, a system similar to emulsion or microemulsion, depending on the amount of ethanol in the reaction mixture. It is interesting to point out that the protein isolate used did not have any fat residual. In this study, the increase in water absorption rate of modified treated with ethanol was much higher than $50 \%$, it might be related with the amount of fat present in the hydrolysates (ranging from 7 to $9 \%$ ). In this case, ethanol improves the denaturation of $\beta$-sheets structures and also removes fat residuals. Such fat, present in modified protein may have prevented the modified isolates without the presence of ethanol from absorbing more water.

\subsection{Effect of ionic strength over the swelling capacity of gels}

The rate of water-uptake is mainly related to the characteristics of the external solution, for example, ionic power, nature of the polymer, elasticity of tridimensional network, presence of hydrolytic functional groups and extent of modification. The ability of swelling of "anionic" hydrogels in several saline solutions is lower than in distillated water ${ }^{[33]}$. Thus, loss of capacity in water-uptake is regularly justified by the "screening effect" of cations added, which cause flaws in electrostatic anion-anion repulsions ${ }^{[34]}$.

Figure 2 shows the behavior of modified isolates, treated or not, with ethanol, when exposed to different salt concentrations for $24 \mathrm{~h}$.

Hydrogels produced from fish isolates are very sensitive to saline solutions; a drop in water absorption between 60 and $90 \%$ was detected when a lower concentration of $0.01 \mathrm{M} \mathrm{NaCl}$ was applied. All of the immersed gels in saline solution $0.15 \mathrm{M}$ had reductions higher than $90 \%$ in the water uptake capacity while compared to the same immersed in distillated water. Similar studies of hydrogel production with soy and fish protein modified by ethylenediamine tetraacetic dianhydride and added with glutaraldehyde demonstrated the same behavior in terms of ionic strength ${ }^{[5]}$.

Sadeghi and Hosseinzadeh ${ }^{[35]}$ investigated a hydrogel formed from starch and evaluated at different concentrations of $\mathrm{NaCl}$. It demonstrated to be more resistant to saline conditions than the protein hydrogel produced in this study, as it absorbed $87 \mathrm{~g}_{\text {water }} / \mathrm{g}_{\text {dry gel }}$ in a concentration of $0.01 \mathrm{M}$ and in $0.15 \mathrm{M}$ it was still able to absorb $58 \mathrm{~g}_{\text {water }} / \mathrm{g}_{\text {dry gel }}$. Pourjavadi et al. ${ }^{[36]}$ produced hydrogel from hydrolysis of collagen, reached a water absorption of $58 \mathrm{~g}_{\text {water }} / \mathrm{g}_{\text {gel }}$ in a concentration of $0.15 \mathrm{M} \mathrm{NaCl}$.

Mahdavinia et al. ${ }^{[37]}$ studied the ionic strength of $\kappa$-carrageenan/sodium alginate hydrogel in salt solutions, suc as $\mathrm{CaCl}_{2}, \mathrm{NaCl}$ and $\mathrm{KCl}$. The authors observed a different swelling behavior for each salt solution, the hydrogel disintegrated after $160 \mathrm{~min}$ in the $\mathrm{NaCl}$ solution, for the $\mathrm{CaCl}_{2}$ and $\mathrm{KCl}$ solution the hydrogel swell without any disintegration. Mahdavinia et al. ${ }^{[38]}$ investigated a swelling behavior of a hydrogel made from modified chitosan in two salt solutions $\left(\mathrm{NaCl}\right.$ and $\left.\mathrm{CaCl}_{2}\right)$, and observed that the hydrogel absorbed much more in the $\mathrm{NaCl}$ solution than $\mathrm{CaCl}_{2}$ solution, then the swelling behavior of hydrogels in (a)

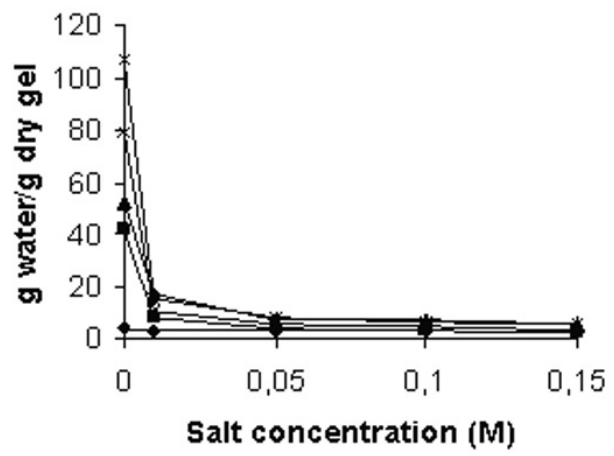

(b)

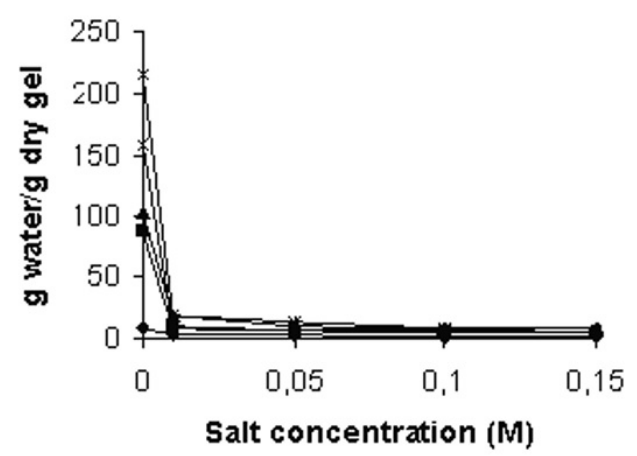

Figure 2. Effect of ionic strength over hydrogels. (a) Alkaline modified isolates (b) acid modified isolates. alkaline and acid isolate without chemical modification; - modified 0.2:1 (EDTAD:protein, p/p); $\boldsymbol{\Delta}$ modified 0.5:1 (EDTAD:protein, p/p); $\times$ modified 0.2:1 treated with ethanol; * modified 0.5:1 treated with ethanol. 
general depends of their structure and the saline solution which it is immersed.

\subsection{Effect of pH over water-uptake capacity}

The $\mathrm{pH}$ affects the water-uptake capacity of protein-based hydrogels produced from fish isolates, as shown in Figure 3. Also, $\mathrm{pH}$ of solutions affects ionization of carboxylic and other ionizable groups ${ }^{[18]}$.

All the samples evaluated reached the maximum of water absorption at $\mathrm{pH} 8$. The same behavior was found by Sadeghi and Hosseinzadeh ${ }^{[35]}$, who studied the influence of $\mathrm{pH}$ on water absorption by a hydrogel produced from starch. According to Hwang and Damodaran ${ }^{[24]}$, the values of $\mathrm{pK}_{1}$, $\mathrm{pK}_{2}$ and $\mathrm{pK}_{3}$ of the carboxylic groups of EDTA are 2, 2.6 and 6.2 , respectively. Hence, theoretically, all carboxylic groups must be fully ionized around $\mathrm{pH} 8$, providing maximum water absorption of water around this $\mathrm{pH}$ value. However, in the study made by these authors, which the hydrogel was produced from fish muscle, water absorption of the hydrogel increased from $\mathrm{pH} 3$ to $\mathrm{pH} 10$, with the maximum reached in the latter.

It is interesting to observe that the non-modified isolates presented a higher value of water absorption at $\mathrm{pH} 3$ when compared with the modified isolate, this may be associated to a higher amount of lysine present in non-modified isolate, since they are protonated in $\mathrm{pH} 3$. The increase in the positive charge of protein, due to protonation of carboxylic groups below $\mathrm{pH} 4$, may cause electrostatic repulsions within the protein matrix allowing water retention at $\mathrm{pH} 3$.

At $\mathrm{pH} 3$, most of the carboxylic groups are in the form of $\mathrm{COOH}$ and the hydrogel has low values of water retention, it can be justified by the presence of hydrolytic non-ionic groups $\mathrm{COOH}$ and $-\mathrm{OH}$ in the polymeric network of hydrogel ${ }^{[35]}$, as well as, many carboxyl anions are protonated, the main anion-anion repulsion forces are eliminated and, consequently, the capacity of water absorption decreases ${ }^{[36]}$. As $\mathrm{pH}$ increases from 4 to 8 , the rate of water absorption increases significantly. Reis et al. ${ }^{[39]}$ noticed that the higher the $\mathrm{pH}$, the higher the water uptake, which was associated to more $\mathrm{COOH}$ groups dissociate to $\mathrm{COO}^{-}$, raising the number of ionized groups in the hydrogel structure. It generates electrostatic repulsion in the ionized groups in the polymer network, which increase water absorption of hydrogels. Similar behaviors on water absorption in different $\mathrm{pH}$ have been reported for other types of hydrogels ${ }^{[29,40,41]}$.

The ionic strength of all the buffers applied in the study of water absorption by hydrogels was $0.01 \mathrm{M}$, it was probably the explanation of low water retention. For example, the acid modification 0.5:1 (EDTAD:protein, $\mathrm{p} / \mathrm{p}$ ) when treated with ethanol absorbed $216.05 \mathrm{~g}_{\text {water }} / \mathrm{g}_{\text {drygel }}$, while the maximum absorption of the same sample at $\mathrm{pH} 8$ was $66.69 \mathrm{~g}_{\text {water }} / \mathrm{g}_{\text {drygel }}$. Hydrogel produced from alkaline isolates, also treated with ethanol reached $137.19 \mathrm{~g}_{\text {water }} / \mathrm{g}_{\text {drygel }}$ and at $\mathrm{pH} 8$, the maximum of water retention was $28.76 \mathrm{~g}_{\text {water }} / \mathrm{g}_{\text {drygel }}$.

For $\mathrm{pH}$ higher than 8 , where all the samples had maximum water holding capacity, there was a slight reduction in $\mathrm{pH} 9$, probably because of the lower ionization of amino acids residues that could keep the water absorption, followed by a new increase in water absorption in $\mathrm{pH} 10$. This increase in swelling capacity of gels at $\mathrm{pH} 10$, according to Hwang and Damodaran ${ }^{[27]}$, is associated with electrostatic repulsion force which is directly proportional to the square charge of molecular network, thus, even though there is a small increase in the charge of the network due to ionization of tyrosine residues $\left(\mathrm{pK}_{3}=9.6\right)$ there will be an increase in electrostatic repulsion inside the network of the gel, resulting in an increase of gel expansion and water retention. Other authors ${ }^{[16]}$ state that growing particles are surrounded by layers of aqueous ethanol solution, which allow the stability of the particles growing in establishing a colloidal system.

\subsection{Reversibility of hydroge/s}

According to Kong and $\mathrm{Li}^{[42]}$, protein-based hydrogels have attracted considerable interest due to their potential biomedical applications. Although various methods have been developed to engineer self-assembling, physically-crosslinked protein hydrogels, exploring novel driving forces to engineer such hydrogels remains challenging. Since the hydrogels (a)

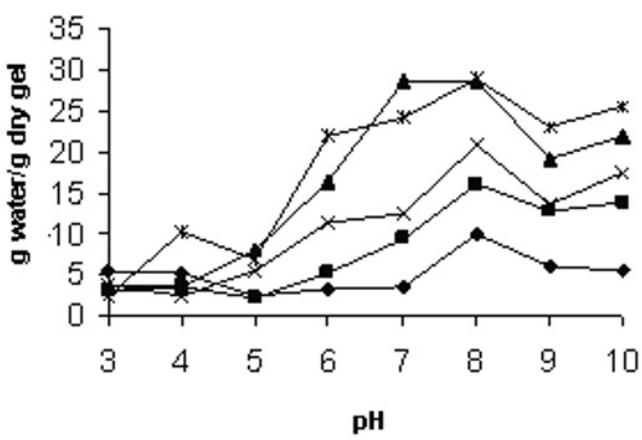

(b)

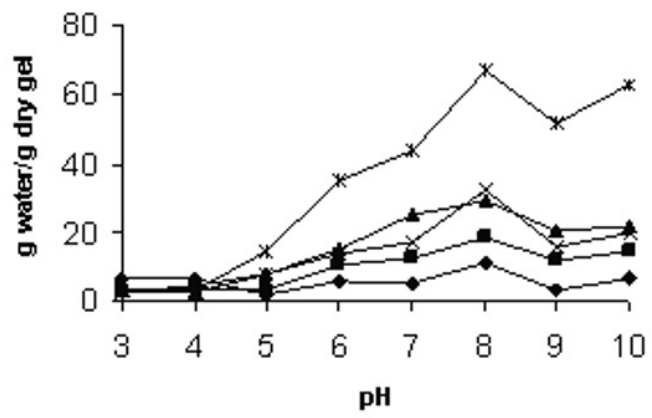

Figure 3. Effect of pH over hydrogels. (a) Alkaline modified isolates (b) acid modified isolates. alkaline and acid isolates without chemical modification; modified 0.2:1 (EDTAD:protein, p/p); $\boldsymbol{\Delta}$ modified 0.5:1 (EDTAD:protein, p/p); $\times$ modified 0.2:1 treated with ethanol; * modified $0.5: 1$ treated with ethanol. 
produced in this study proved to be sensitive to exposition to saline solutions, the capacity of reversibility, absorption and dehydration of gels was investigated. Therefore, a solution of $0.15 \mathrm{M} \mathrm{NaCl}$ was used, as dehydration agent and deionized water for hydration. Figures 4 and 5 show the behavior of the gels during a $36 \mathrm{~h}$ period, in which hydrogels were submitted to subsequent hydrations and dehydrations.

When the gel hydrated for $24 \mathrm{~h}$ was exposed to a saline solution of $0.15 \mathrm{M} \mathrm{NaCl}$, for a period of $2 \mathrm{~h}$, there was a drop of more than $90 \%$ in water content, it occurred for hydrogels produced with both alkaline and acid modified protein. The control samples also had a loss in water content, although it was between 55 and $64 \%$.

Figure 4 clearly shows that the hydrogels produced had good water retention capacity, even after dehydration. Nonetheless, it is noticed that their capacity of water absorption was slightly reduced, after the first dehydration. Once dehydrated the second time, it is observed that there was an increase in the capacity of hydration, when compared to the first dehydration, which can be explained, partly, due to an increase in flexibility of the gel matrix, after repeated dehydrations and hydrations. Hwang and Damodaran ${ }^{[24]}$ studied reversibility of the hydrogel produced from alkaline isolates of fish muscle and obtained a higher water retention capacity when the gel was dehydrated and hydrated again for the first time. However, when the gel is submitted to dehydration for the second time and returned to hydration, it took long to absorb water, 7 times lower than the first time.

Figure 5 shows the behavior of modified protein derived from acid isolates, they had similar behaviors to

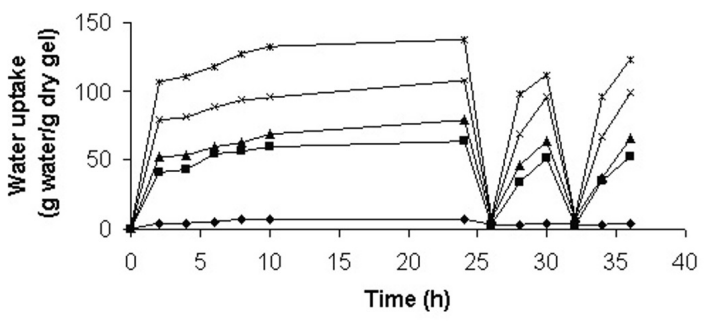

Figure 4. Kinetics of absorption and dehydration of hydrogels produced from alkaline isolates. alkaline isolates without chemical modification; modified 0.2:1 (EDTAD:protein, $\mathrm{p} / \mathrm{p}$ ); $\Delta$ modified 0.5:1 (EDTAD:protein, $\mathrm{p} / \mathrm{p}) ; \times$ modified 0.2:1 treated with ethanol; * modified 0.5:1 treated with ethanol.

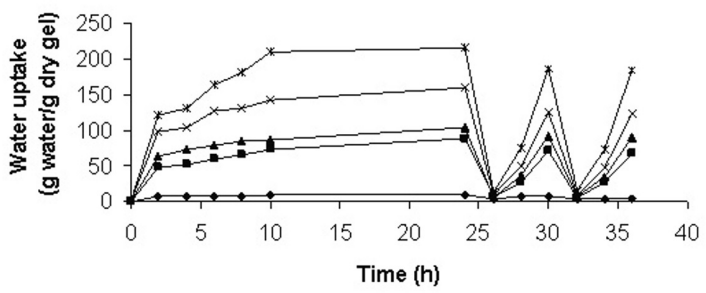

Figure 5. Kinetics of absorption and dehydration of hydrogels produced from alkaline isolates. alkaline isolates without chemical modification; modified 0.2:1 (EDTAD:protein, $\mathrm{p} / \mathrm{p}$ ); $\Delta$ modified 0.5:1 (EDTAD:protein, $\mathrm{p} / \mathrm{p}) ; \times$ modified 0.2:1 treated with ethanol; $*$ modified $0.5: 1$ treated with ethanol. protein alkaline modified. These hydrogels also had good hydration capacity, after successive dehydrations. Another fact noticed was that dehydration in $0.15 \mathrm{M} \mathrm{NaCl}$ is faster than next hydration. While gels lose approximately $90 \%$ of water content in $2 \mathrm{~h}$ immersion, these take approximately $4 \mathrm{~h}$ to hydrate again. This slower water absorption may be justified by a low dissociation rate of ions linked to the polymer network.

\section{Conclusion}

The protein isolates produced from fish wastes and modified chemically were able to form biopolymers as hydrogels with superabsorbent properties. The results of this study indicate that protein hydrogels produced with crosslinking when treated with ethanol enhance their water swelling properties. For the acid solubilized protein, it was obtained an increase of $209 \%$ and $172 \%$ for the alkaline solubilized protein.

Besides raising the water retention capacity of hydrogels, the modification with ethanol offers other advantages, such as, dehydration of the gel that does not require dryness for a long period, extraction of odorous compounds of low molecular weight, which improves its acceptance by the consumer, mainly when it comes from a hydrogel formulated from fish, it also eliminates any non-reactive residue of glutaraldehyde which may be present in the gel. Ethanol applied in the process can also be easily recovered and recycled.

The reversibility of swelling capacity of hydrogels shown proves that hydrogels produced from fish protein isolates can be repeatedly applied, without losing their hydration capacity, hence; they can be used in the dehydration processes in many industries, such as, pharmaceutical, food, chemical, among others. The potential applications of such hydrogels could be in diapers and plants water supply, the main advantage of those hydrogels over the conventional ones is the degradability, they are made from proteins, and can degrade much faster than the conventional polymers. These hydrogels have an eco-friendly nature, the use of fish wastes to produce them is a good destiny for those sub-products, because in most of the cases the fish wastes are disposed directly in the environment causing a great environmental problem.

\section{Acknowledgements}

This work was supported by grants from the National Council for Scientific and Technological Development of Brazil (CNPq), and the Coordination for Improvement of Higher Education Personnel of Brazil (CAPES).

\section{References}

1. Huang, P.-S., Boyken, S. E., \& Baker, D. (2016). The coming of age of de novo protein design. Nature, 537(7620), 320-327. http://dx.doi.org/10.1038/nature19946. PMid:27629638.

2. Martins, V. G., Palezi, S. C., Costa, J. A. V., \& Prentice, C. (2014). Hydrolysis of insoluble fish protein residue from Whitemouth croaker (Micropogonias furnieri) by fungi. Brazilian Archives of Biology and Technology, 57(1), 96-102. http://dx.doi.org/10.1590/S1516-89132014000100014. 
3. Kristinsson, H. G., \& Rasco, B. A. (2000). Fish protein hydrolysates: production, biochemical, and functional properties. Critical Reviews in Food Science and Nutrition, 40(1), 43-81. http://dx.doi.org/10.1080/10408690091189266. PMid:10674201.

4. Freitas, I. R., Cortez-Vega, W. R., \& Prentice, C. (2015). Recovery of anchovy (Engraulis anchoita) and whitemouth croaker (Micropogonias furnieri) proteins by alkaline solubilisation process. Acta Alimentaria, 44(2), 221-228. http://dx.doi. org/10.1556/AAlim.2014.0005.

5. Martins, V. G., Costa, J. A. V., Damodaran, S., \& Prentice, C. (2011). Chemical modification and structural analysis of protein isolates to produce hydrogel using Whitemouth croaker (Micropogonias furnieri) wastes. Applied Biochemistry and Biotechnology, 165(1), 279-289. http://dx.doi.org/10.1007/ s12010-011-9250-y. PMid:21505805.

6. Halim, N. R. A., Yusof, H. M., \& Sarbon, N. M. (2016). Functional and bioactive properties of fish protein hydrolysates and peptides: a comprehensive review. Trends in Food Science \& Technology, 51, 24-33. http://dx.doi.org/10.1016/j. tifs.2016.02.007.

7. Cortez-Vega, W. R., Pizato, S., Souza, J. T. A., \& Prentice, C. (2014). Using edible coatings from Whitemouth croaker (Micropogonias furnieri) protein isolate and organo-clay nanocomposite for improve the conservation properties of fresh-cut Formosa papaya. Innovative Food Science \& Emerging Technologies, 22, 197-202. http://dx.doi.org/10.1016/j. ifset.2013.12.007.

8. Guerard, F., Guimas, L., \& Binet, A. (2002). Production of tuna waste hydrolysates by a commercial neutral protease preparation. Journal of Molecular Catalysis. B, Enzymatic, 19-20(2), 489498. http://dx.doi.org/10.1016/S1381-1177(02)00203-5.

9. Rathna, G. V. N., \& Damodaran, S. (2002). Effect of nonprotein polymers on water-uptake properties of a fish protein-based hydrogel. Journal of Applied Polymer Science, 85(1), 45-51. http://dx.doi.org/10.1002/app.10566.

10. Matsushima, A., Kodera, Y., Hiroto, M., Nishimura, H., \& Inada, Y. (1996). Bioconjugates of proteins and polyethylene glycol: potent tools in biotechnological processes. Journal of Molecular Catalysis. B, Enzymatic, 2(1), 1-17. http://dx.doi. org/10.1016/1381-1177(96)00003-3.

11. DeSantis, G., \& Jones, B. (1999). Chemical modification of enzymes for enhanced functionality. Current Opinion in Biotechnology, 10(4), 324-330. http://dx.doi.org/10.1016/ S0958-1669(99)80059-7. PMid:10449313.

12. Kurniawan, L., Qiao, G. G., \& Zhang, X. (2007). Chemical modification of wheat protein-based natural polymers: grafting and cross-linking reactions with poly(ethylene oxide) diglycidyl ether and ethyl diamine. Biomacromolecules, 8(9), 2909-2915. http://dx.doi.org/10.1021/bm0703719. PMid:17663528.

13. Solanki, K., Shah, S., \& Nath Gupta, M. (2008). Chemical modification of alpha-chymotrypsin for obtaining high transesterification activity in low water organic media. Biocatalysis and Biotransformation, 26(4), 258-265. http:// dx.doi.org/10.1080/10242420801897361.

14. Iannace, S., Nicolais, L., \& Huang, S. J. (1997). Water sorption of glycol-modified cross-linked gelatin-based hydrogels. Journal of Materials Science, 32(6), 1405-1408. http://dx.doi. org/10.1023/A:1018533429283.

15. Kunioka, M., \& Choi, H. J. (1998). Hydrolytic degradation and mechanical properties of hydrogels prepared from microbial poly(amino acid)s. Polymer Degradation \& Stability, 59(1-3), 33-37. http://dx.doi.org/10.1016/S0141-3910(97)00181-X.

16. García Sánchez, L. G. J., \& Cortés Ortega, J. A. (2014). Síntesis de hidrogeles de acrilamida en soluciones acuosas de etanol.
Polimeros: Ciência e Tecnologia, 24(6), 752-756. http://dx.doi. org/10.1590/0104-1428.1663.

17. Chen, J., Ma, X., Dong, Q., Song, D., Hargrove, D., Vora, S. R., Ma, A. W. K., Lu, X., \& Lei, Y. (2016). Self-healing of thermally-induced, biocompatible and biodegradable protein hydrogel. RSC Advances, 6(61), 56183-56192. http://dx.doi. org/10.1039/C6RA11239K.

18. Park, T. G., \& Hoffman, A. S. (1992). Synthesis and characterization of $\mathrm{pH}$-and/or temperature sensitive hydrogels. Journal of Applied Polymer Science, 46(4), 659-671. http:// dx.doi.org/10.1002/app.1992.070460413.

19. Bae, K. H., \& Kurisawa, M. (2016). Emerging hydrogel designs for controlled protein delivery. Biomaterials Science, 4(8), 1184-1192. http://dx.doi.org/10.1039/C6BM00330C. PMid:27374633.

20. Hideki, O. (1992). Handbook of polymer degradation. New York: Marcel Dekker.

21. Hellriegel, J., Günther, S., Kampen, I., Bolea Albero, A., Kwade, A., Böl, M., \& Krull, R. (2014). Biomimetic gellanbased hydrogel as a physicochemical biofilm model. Journal of Biomaterials and Nanobiotechnology, 5(2), 83-97. http:// dx.doi.org/10.4236/jbnb.2014.52011.

22. Rathna, G. V. N., Li, J., \& Gunasekaran, S. (2004). Functionallymodified egg white albumen hydrogels. Polymer International, 53(12), 1994-2000. http://dx.doi.org/10.1002/pi.1611.

23. Martins, V. G., Costa, J. A. V., \& Prentice-Hernández, C. (2009). Hidrolisado proteico de pescado obtido por vias química e enzimática a partir de corvina (Micropogonias furnieri). Química Nova, 32(1), 61-66. http://dx.doi.org/10.1590/S010040422009000100012 .

24. Hwang, D. C., \& Damodaran, S. (1997). Synthesis and properties of fish protein-based hydrogel. Journal of the American Oil Chemists 'Society, 74(9), 1165-1171. http://dx.doi.org/10.1007/ s11746-997-0041-0.

25. Scopes, R. K. (1974). Measurement of protein by spectrophotometry at $205 \mathrm{~nm}$. Analytical Biochemistry, 59(1), 277-282. http:// dx.doi.org/10.1016/0003-2697(74)90034-7. PMid:4407487.

26. Hall, R. J., Trinder, N., \& Givens, D. I. (1973). Observations on the use of 2,4,6-trinitrobenzene sulphonic acid for the determination of available lysine in animal protein concentrates. Analyst, 98(1170), 673-686. http://dx.doi.org/10.1039/ an9739800673. PMid:4753164.

27. Hwang, D. C., \& Damodaran, S. (1996). Chemical modification strategies for synthesis of protein-based hydrogel. Journal of Agricultural and Food Chemistry, 44(3), 751-758. http:// dx.doi.org/10.1021/j99503826.

28. Thiansilakul, Y., Benjakul, S., \& Shahidi, F. (2007). Compositions, functional properties and antioxidative activity of protein hydrolysates prepared from round scad (Decapterus maruadsi). Food Chemistry, 103(4), 1385-1394. http://dx.doi.org/10.1016/j. foodchem.2006.10.055

29. Hwang, D., \& Damodaran, S. (1998). Carboxyl modified superabsorbent protein hydrogel. US Patent No 5,847,089. Alexandria.

30. Buchholz, F. L. (1994). Preparation methods of superabsorbent polyacrylates. In American Chemical Society. Superabsorbent polymers: science and technology (ACS Symposium Series, Vol. 573). Washington: ACS.

31. George, M., \& Abraham, T. E. (2007). pH sensitive alginateguar gum hydrogel for the controlled delivery of protein drugs. International Journal of Pharmaceutics, 335(1-2), 123-129. http://dx.doi.org/10.1016/j.ijpharm.2006.11.009. PMid:17147980.

32. Tsai, H.-S., \& Wang, Y.-Z. (2008). Properties of hydrophilic chitosan network membranes by introducing binary crosslink 
agents. Polymer Bulletin, 60(1), 103-113. http://dx.doi. org/10.1007/s00289-007-0846-X.

33. Pourjavadi, A., Amini-Fazl, M. S., \& Hosseinzadeh, H. (2005). Partially hydrolyzed crosslinked alginate-graft-polymethacrylamide as a novel biopolymer-based superabsorbent hydrogel having pH-responsive properties. Macromolecular Research, 13(1), 45-53. http://dx.doi.org/10.1007/BF03219014.

34. Peppas, N. A., \& Mikes, A. G. (1986). Hydrogels in Medicine and Pharmacy. Vol.1, CRC Press: Boca Raton, FL.

35. Sadeghi, M., \& Hosseinzadeh, H. (2008). Synthesis of starchpoly(sodium acrylate-co-acrylamide) superabsorbent hydrogel with salt and $\mathrm{pH}-$ responsiveness properties as a drug delivery system. Journal of Bioactive and Compatible Polymers, 23(4), 381-404. http://dx.doi.org/10.1177/0883911508093504.

36. Pourjavadi, A., Kurdtabar, M., Mahdavinia, G. R., \& Hosseinzadeh, H. (2006). Synthesis and super-swelling behavior of a novel protein-based superabsorbent hydrogel. Polymer Bulletin, 57(6), 813-824. http://dx.doi.org/10.1007/s00289-006-0649-5.

37. Mahdavinia, G. R., Rahmani, Z., Karami, S., \& Pourjavadi, A. (2014). Magnetic/pH-sensitive $\kappa$-carrageenan/sodium alginate hydrogel nanocomposite beads: preparation, swelling behavior, and drug delivery. Journal of Biomaterials Science, 25(17), 1891-1906. http://dx.doi.org/10.1080/09205063.2014.95616 6. PMid:25197770.

38. Mahdavinia, G. R., Pourjavadi, A., Hosseinzadeh, H., \& Zohuriaan, M. J. (2004). Modified chitosan 4. Superabsorbent hydrogels from poly(acrylic acid-co-acrylamide) grafted chitosan with salt and $\mathrm{pH}$-responsiveness properties. European Polymer Journal, 40(7), 1399-1407. http://dx.doi.org/10.1016/j. eurpolymj.2004.01.039.

39. Reis, A. V., Guilherme, M. R., Cavalcanti, O. A., Rubira, A. F., \& Muniz, E. C. (2006). Synthesis and characterization of pH-responsive hydrogels based on chemically modified Arabic gum polysaccharide. Polymers, 47(6), 2023-2029. http://dx.doi. org/10.1016/j.polymer.2006.01.058.

40. Toit, L. C. D., Pillay, V., \& Danckwerts, M. P. (2006). Application of synergism and variation in ionic compatibilities within a hydrophilic polymeric sodium starch glycolate-kappacarrageenan combination: textural profiling of the suspension behavior. Journal of Bioactive and Compatible Polymers, 21(2), 107-122. http://dx.doi.org/10.1177/0883911506062975.

41. Zhang, J., Yuan, K., Wang, Y. P., Zhang, S. T., \& Zhang, J. (2007). Preparation and $\mathrm{pH}$ responsive behavior of poly(vinyl alcohol) - chitosan- poly(acrylic acid) full-IPN hydrogels. Journal of Bioactive and Compatible Polymers, 22(2), 207218. http://dx.doi.org/10.1177/0883911506076046.

42. Kong, N., \& Li, H. (2015). Protein fragment reconstitution as a driving force for self-assembling reversible protein hydrogels. Advanced Functional Materials, 25(35), 5593-5601. http:// dx.doi.org/10.1002/adfm.201502277.

Received: Oct. 06, 2016

Revised: Jan. 24, 2017

Accepted: June 05, 2017 